(REVIEW ARTICLE)

\title{
Offspring of the divorce's victim
}

\author{
Basem Abbas Al Ubaidi * \\ Consultant Family Physician, Ministry of Health, Assistant professor at Arabian Gulf University (AGU), Kingdom of Bahrain.
}

Magna Scientia Advanced Biology and Pharmacy, 2021, 02(02), 001-005

Publication history: Received on 25 March 2021; revised on 03 May 2021; accepted on 06 May 2021

Article DOI: https://doi.org/10.30574/msabp.2021.2.2.0018

\begin{abstract}
Children of divorce may suffer from emotional, academic, and social problems. Children of divorce need primary and social worker's attention. Children of divorce may have many social, emotional scars, which easily bleeds due to the unhealthy healing process.
\end{abstract}

Keywords: Children of the divorce; Parental divorce; Couple divorce; Parental separation; Child stress; Child maladjustment.

\section{Introduction}

There is a significant increase in divorces worldwide, which substantially dramatically affects particular children [1]. Numerous studies have found one-third of Children of Divorce (CODs) are associated with either denial of the divorce and or separation symptoms. Although selected of CODs will have worries, fear of abandonment by a parent, upset from repeated hearing bad names about another partner. Sometimes, CODs will have an anxious feeling of divided loyalties or a triangulated backbone with one parent. CODs will be preoccupied with what was happening and will have further academic difficulties (lower grades and dropping out of school). Occasionally, CODs will have more significant disruptive behaviors (e.g., anger, hostility, refusals to talk, or reluctance to see another parent). Besides, they may have acting out symptoms, withdraw from social activities, and oppositional with authority figures [1].

Moreover, the adulthood CODs may engage in many excessive fights and conduct stealing behavior. They may engage in drug-abusing manners ( such as alcohol and other illegal drugs. Infrequently, CODs will also suffer from many physical symptoms (such as s lethargy, sleep, eating disorders, and inflict self-injuries). Intermittently, CODs will either regress to their immaturity behavior or quick progress to their hyper-maturity manners. Mostly, CODs are always thinking about their parent reconciliation, blaming themselves, feels guilty, and being responsible for their parents' divorce [24].

While, victims of CODs may suffer in their future adulthood from increased incidence of depressive mood, lower selfesteem, emotional distress, poverty, and academic failure. Besides, they may have a higher incidence of early and risky sexual activity, illegal childbirth and earlier marriage, marital disharmony, and a high divorce rate [2-6].

A meta-analysis study has shown a causal relationship between parental separation and the adverse effects on their psychological, academic, and social impairments. Other studies had focused on identifying family dysfunction before parental divorce (e.g., parental conflict, inadequate parenting skills, economic stressors, and low parent-child interactions) $[7,8]$. Other longitudinal studies on the separated couple found a causal effect on offspring functioning or malfunctioning before and after the separation [7-10].

\footnotetext{
${ }^{*}$ Corresponding author: Basem Abbas Al Ubaidi

Consultant Family Physician, Ministry of Health, Kingdom of Bahrain. Assistant professor at Arabian Gulf University (AGU).. 


\section{Discussion}

The psychological impact on CODs depends on the intensity, frequency, and duration of the family disharmony. At the same time, the psychological impact will decrease on their quality of the family and or social support system [11].

There is different gender of the CODs type of their future suffering. There is an increase in incidence rates of social maladjustment and poor school academic performance in males victims. Besides, they will have greater externalizing their distress, more frustration and hurt, quickly getting trouble in school, and an increased incidence of peers and parents fighting in males victims [11].

While, in females victims, there is an increased incidence of internalizing their pain, more depression, headaches or stomach aches, changes in eating and sleeping patterns [11]. Eventually, most divorces or marital disharmony or couple unhappiness can prevent their CODs future problems and have CODs that can healthy survive and progress in their lives [12].

While fracturing parents' marital harmony will cause long-term, deep unconscious, and severe emotional scars, which might increase to three folds among COD victims. They cannot remove their painful memory of the discomfort and misperception of the separated world of the CODs' feelings $[13,14]$. The signs of CODs stress are different depending on the victims' age when the parent was divorced (Table 1) [15].

Table 1 Signs of the Stress and Adjustment Problems at Infants and Toddlers in Different Age Group of Children

\begin{tabular}{|c|c|}
\hline $\begin{array}{l}\text { Infants and } \\
\text { Toddlers }\end{array}$ & $\begin{array}{l}\text {-Sleeping, eating, or digestive problems. } \\
\text {-Regression regarding sleeping (difficulty going to sleep; frequent waking) or difficulty in } \\
\text { toilet training or eating. } \\
\text {-Delayed development of walking and speaking. } \\
\text {-General crankiness, difficulty leaving parent; clinginess, temper tantrums, and excessive } \\
\text { crying. }\end{array}$ \\
\hline 3 - 5 Years & $\begin{array}{l}\text {-Heightened irritability, aggression, temper tantrums, } \\
\text {-Regression in toilet training, thumb sucking. } \\
\text {-The immature grip of what has happened; confused; making up fictional stories. } \\
\text {-Guilty and blaming themselves. } \\
\text {-Bedtime anxiety; fitful/fretful sleep; frequent waking. } \\
\text {-Fear of being abandoned by both parents; heightened separation anxiety or excessive } \\
\text { clinging. } \\
\text {-More significant irritability, aggression, increased temper tantrums. }\end{array}$ \\
\hline 6-9 Years & $\begin{array}{l}\text {-Physical manifestations of stress, including headaches, stomachaches, tiredness. } \\
\text {-Pervasive sadness; depressed mood, increased anxiety, feeling abandoned and rejected. } \\
\text {-Excessive, inappropriate crying and weeping. } \\
\text {-Afraid of their worst fears coming true. } \\
\text {-Reconciliation fantasies. } \\
\text { - Loyalty conflicts and physically torn apart. } \\
\text {-Problems with impulse control; disorganized behavior. } \\
\text {-School refusal or decrease in academic performance. }\end{array}$ \\
\hline 10-12 Years & $\begin{array}{l}\text {-Able to see family interruption history. } \\
\text {-Fear of loneliness. } \\
\text {-Intense anger at the parent they blame for causing the divorce. } \\
\text {-Physical complaints; headaches and stomach aches. } \\
\text {-Overactive behavior to avoid thinking about the divorce. } \\
\text {-They feel ashamed of what's happening in their family; feel they are different from other } \\
\text { children. }\end{array}$ \\
\hline V. Adoles & $\begin{array}{l}\text { dolescents Depression; acting-out behavior including substance abuse, precocious sexual } \\
\text { tivities, suicidal thoughts or self-injurious behavior, uncontrollable anger. }\end{array}$ \\
\hline
\end{tabular}




\begin{tabular}{|l|l|}
\hline & -Fear of being isolated and lonely. \\
-Experience parents as leaving them; feel parents are not available to them. \\
-Feel hurried to achieve independence. \\
-Feel in competition with parents. \\
-Worry about their future lives and marriage; preoccupied with the survival of relationships. \\
-Discomfort with a parent's dating and sexuality. \\
-Chronic fatigue and difficulty concentrating. \\
-Grief reaction of the family.
\end{tabular}

Psychological harm to specific CODs can interfere with the children and young youth's emotional status, either associated with increased incidence of one psychiatric or two mental disorders. They may suffer from long-term behavior changes, such as school difficulties, school suspensions, abandonment, fear. Besides, there will be an increased incidence of teenage delinquency, violence in youth, and high suicidal attempts $[16,17]$.

Supposing the victims of the CODs will be married. In that case, they may regret their unhappy partnership, conflict escalation, diminutive communication skills, more arguing, frequently shouting, and ends to assault their partners. Consequently, it may lead to an increased incidence of the inter-generational divorce cycle $[18,19]$. Correspondingly, CODs will have particular spiritual harm with unconscious, bitter anger and disappointment to the responsible parent, significant difficulty in future loving relationships, and even less faith in God's trust [19].

The risk factors for divorce are many reasons such as poor couple communication skills, co insufficient partner attention, infidelity, insecurity, selfishness and loneliness, excessive anger, controlling, and disrespectful behaviors [20]. Fears and the virtue of trust of various CODs are affected, such as faith in a life-long commitment and marital fulfillment and happiness; instead, they will substitute cohabitate, not sharing complete partner responsibility [20, 21]. Excessive anger and the virtue of forgiveness towards responsible parent or unconsciously misdirected to the future spouse, or being expressed as self-destructive behaviors [22].

The bitter anger feeling of the CODs is needing for conflict resolving therapy through covering their resentment mood. The psychiatric physician may use cognitive behavioral therapy. CODs need to work on their negative emotions and to have spiritual forgiveness [22]. The benefits of forgiveness are speed healing for their emotional wounds, decreased inner anger, reduced sadness and anxiety, and increased self-esteem [23]. Some of the CODs feel frequent sadness, unhappy emotions, and unenjoyment with their parental responsibilities, and a loss of hope virtue [23].

In contrast, most CODs regularly struggles with their inappropriate responsibility to distressed parents. If CODs lose their family intimacy, they will replace it with love from other friends or couples. Growth of the inside hope and faith can be reconstructed through emergent trust, strengthening self-giving, keeping an open heart, and building future confidence [23].

Selfishness and irresponsibilities are the leading cause of marital- divorce, which may be unconsciously transmitted to particular CODs as a trait, making it challenging to maintain a lifelong marital commitment. While, the healing process for selfishness is growing in their virtues of generosity, self-denial, and sacrificial giving. Infrequently, some of the CODs will suffer from a lack of self-confidence, loss of self-identity, and impaired respect to role models, which needs future gratitude for personality strengths [24].

\section{Conclusion}

The children are living mirror reflections of their parents. If the divorce happened in the family, CoDs might have permanent emotional/psychological, spiritual, academic, and social wounds that will impact their future healthy relationship. Profoundly harms CODs may suffer from fear, anger, sadness, and insecurity. Besides, virtual and theological growth will minimize their influence. Not all parental divorce or separation necessarily dooms a child to have significant, impairing problems. Children and youth who have the painful experience of parental separation/divorce will experience significant emotional restlessness. The causes of divorce are primarily due to poor parenting, financial difficulties, or infidelity.

\section{Implications}


Raise the importance of the marriage and family union scarifying by policymakers, scholars, professionals. Focus on economic, social, and psychological resources to improve the lives of families. Strengthen the fact that most people from divorced families do not have significant or diagnosable problems, but parental separation/divorce constitutes a severe public health problem.

Thus, public policy reforms should take legal policies and have a comprehensive approach to strengthening marriage and reducing the risks of the victims of the CODs sufferings.

\section{References}

[1] Casper, L. M., \& Bianchi, S. M. (2001). Continuity and change in the American family. Sage Publications.

[2] Amato, P. R. (2010). Research on divorce: Continuing trends and new developments. Journal of marriage and family, 72(3), 650-666.

[3] Lansford, J. E. (2009). Parental divorce and children's adjustment. Perspectives on psychological science, 4(2), 140152.

[4] Kelly, J. B., \& Emery, R. E. (2003). Children's adjustment following divorce: Risk and resilience perspectives. Family Relations, 52(4), 352-362.

[5] Cherlin, A. J., Chase-Lansdale, P. L., \& McRae, C. (1998). Effects of parental divorce on mental health throughout the life course. American Sociological Review, 239-249.

[6] Hetherington, E. M., \& Kelly, J. (2002). For better or for worse: Divorce reconsidered. NATIONAL REVIEW-355370BRISTOL CONNECTICUT-, 54(5), 50-51.

[7] Malone, P. S., Lansford, J. E., Castellino, D. R., Berlin, L. J., Dodge, K. A., Bates, J. E., \& Pettit, G. S. (2004). Divorce and child behavior problems: Applying latent change score models to life event data. Structural Equation Modeling, 11(3), 401-423.

[8] Strohschein, L. (2005). Parental divorce and child mental health trajectories. Journal of Marriage and Family, 67(5), 1286-1300.

[9] Emery, R. E., Otto, R. K., \& O'donohue, W. T. (2005). A critical assessment of child custody evaluations: Limited science and a flawed system. Psychological Science in the Public Interest, 6(1), 1-29.

[10] Al-Ubaidi, B. A. (2017). The psychological and emotional stages of divorce. Family Medicine and Disease Prevention, 3(3), 6.

[11] Markman, H. J., Stanley, S. M., \& Blumberg, S. L. (2010). Fighting for your marriage: A deluxe revised edition of the classic best-seller for enhancing marriage and preventing divorce. John Wiley \& Sons.

[12] Marquardt, E. (2006). Between two worlds: The inner lives of children of divorce. Harmony.

[13] Pickar, D. B. (2003). Identifying children's stress responses to divorce. Sonoma Medicine, 54, 15-17.

[14] Merikangas, K. R., He, J. P., Burstein, M., Swanson, S. A., Avenevoli, S., Cui, L., ... \& Swendsen, J. (2010). Lifetime prevalence of mental disorders in US adolescents: results from the National Comorbidity Survey ReplicationAdolescent Supplement (NCS-A). Journal of the American Academy of Child \& Adolescent Psychiatry, 49(10), 980989.

[15] Amato, P. R. (2005). The impact of family formation change on the next generation's cognitive, social, and emotional well-being. The future of children, 75-96.

[16] Hymowitz, K., Carroll, J. S., Wilcox, W. B., \& Kaye, K. (2013). Knot yet: The benefits and costs of delayed marriage in America.

[17] Webster, P. S., Orbuch, T. L., \& House, J. S. (1995). Effects of childhood family background on adult marital quality and perceived stability. American Journal of Sociology, 101(2), 404-432.

[18] Hawkins, A. J., Willoughby, B. J., \& Doherty, W. J. (2012). Reasons for divorce and openness to marital reconciliation. Journal of Divorce \& Remarriage, 53(6), 453-463.

[19] Wilcox, W. B. (2013). Men and women often expect different things when they move in together-the Atlantic.

[20] Fitzgibbons, R. P. (1986). The cognitive and emotive uses of forgiveness in the treatment of anger. Psychotherapy: Theory, Research, Practice, Training, 23(4), 629. 
[21] Reed, G. L., \& Enright, R. D. (2006). The effects of forgiveness therapy on depression, anxiety, and posttraumatic stress for women after spousal emotional abuse. Journal of consulting and clinical psychology, 74(5), 920.

[22] Paulus II, J. (1996). Offer forgiveness and receive peace: 1997 World Day of Peace message (December 8, 1996). Origins, 26.

[23] David, A., \& Melanie, W. (2013). Wayward sons: The emerging gender gap in labor markets and education. Third Way Report.

[24] Peterson, C., \& Seligman, M. E. (2004). Character strengths and virtues: A handbook and classification (Vol. 1). Oxford University Press. 